\title{
EFEKTIFITAS ANTIBIOTIK TERHADAP PERUBAHAN SUHU DAN LEUKOSIT PADA PASIEN PNEUMONIA
}

\author{
Rahmawati Raising ${ }^{1}$, Vivi Rosalina ${ }^{2}$, \\ ${ }^{1}$ Program Studi S1 Farmasi, Stikes Bhakti Husada Mulia Madiun \\ ${ }^{2}$ Program Studi DIII Farmasi, Stikes Bhakti Husada Mulia Madiun \\ E-mail: Rahmawati.raising@gmail.com
}

\begin{abstract}
ABSTRAK
Pneumonia merupakan salah satu penyakit infeksi saluran pernafasan yang banyak menjadi penyebab kematian terutama di negara berkembang. Sebagian besar pneumonia disebabkan oleh mikroorganisme dan sebagian kecil disebabkan oleh hal lain seperti aspirasi dan radiasi. Bakteri yang sering menyebabkan pneumonia adalah Streptococcus Pneumoniae, Haemophilus influenzae, dan Staphylococcus aureus. Pada pemeriksaan penunjang terdapat peningkatan jumlah leukosit, biasanya lebih dari 10.000/ul kadang-kadang mencapai 30.000/ul, Pengobatan pneumonia terdiri atas antibiotik dan pengobatan suportif. Tujuan dari penelitian ini adalah untuk menganalisis efektifitas antibiotik terhadap perubahan suhu dan leukosit pada pasien pneumonia. Penelitian ini merupakan penelitian studi non eksperimental yaitu cross sectional dan retrospektif. Penelitian di lakukan di Rumah Sakit Dr Soedono Madiun selama 3 bulan januari-maret 2019 diperoleh 45 subjek, tehnik pengambilan data subjek yang didiagnosisi pneumonia secara purposive sampling data dan data yang diambil merupakan data yang telah memenuhi kriteria inklusi. Uji yang digunakan ialah Shapiro-Wilk karena jumlah sampel kecil (kurang dari 50). Perbedaan kadar suhu dan leukosit antara kedua kelompok menggunakan uji $\mathrm{t}$ bebas (independent t-test). Berdasarkan hasil penelitian efektifitas antibiotik terhadap perubahan suhu dan kadar leukosit pada pasien pneumonia, maka dapat disimpulkan bahwa pemberian antibiotik dapat menurunkan suhu dan kadar leukosit pada perwatan selama beberapa hari secara bermakna.
\end{abstract}

\section{Kata kunci $\quad$ : Antibiotik, Suhu, Leukosit, Pneumonia}

\begin{abstract}
Pneumonia is one of the respiratory infections that causes death, especially in developing countries. Most pneumonia is caused by microorganisms and a small part is caused by other things such as aspiration and radiation. The bacteria that often cause pneumonia are Streptococcus Pneumoniae, Haemophilus influenzae, and Staphylococcus aureus. In investigations there is an increase in the number of leukocytes, usually more than 10,000 / ul sometimes reaching 30,000 / ul, pneumonia treatment consists of antibiotics and supportive treatment. The purpose of this study was to analyze the effectiveness of antibiotics against changes in temperature and leukocytes in pneumonia patients. This research is a non-experimental study that is cross sectional and retrospective. Research conducted at Dr Soedono Madiun Hospital for 3 months in January-March 2019 obtained 45 subjects, data collection techniques for subjects diagnosed with pneumonia by purposive sampling data and the data taken was data that met the inclusion criteria. The test used is Shapiro-Wilk because the number of samples is small (less than 50). Differences in temperature and leukocyte levels between the two groups using the independent t-test. Based on the results of the study of the effectiveness of antibiotics on changes in temperature and levels of leukocytes in patients with pneumonia, it can be concluded that the administration of antibiotics can reduce the temperature and levels of leukocytes in the treatment for several days significantly
\end{abstract}

Keywords $\quad$ : Antibiotics, Temperature, Leukocytes, Pneumonia 


\section{PENDAHULUAN}

Pneumonia merupakan salah satu penyakit infeksi saluran pernafasan yang banyak menjadi penyebab kematian terutama di negara berkembang.Pneumonia merupakan penyakit terbesar kedua sesudah diare yang menyebabkan kematian. Riset kesehatan dasar tahun 2013 menunjukan prevalensi penderita pneumonia di Indonesia sebesar 4,5\%. Sebagian besar pneumonia disebabkan oleh mikroorganisme dan sebagian kecil disebabkan oleh hal lain seperti aspirasi dan radiasi. Pneumonia di negara berkembang terutama disebabkan oleh bakteri. Bakteri yang sering menyebabkan pneumonia adalah Streptococcus Pneumoniae, Haemophilus influenzae, dan Staphylococcus aureus (Nur, 2016).

Diagnosis pada pneumonia dilihat dari gambaran klinis dan pemeriksaan penunjang. Dimana untuk gambaran klinis biasanya ditandai dengan demam, menggigil, suhu tubuh meningkat dapat melebihi $40^{\circ} \mathrm{C}$, batuk dengan dahak mukoid atau purulen kadang - kadang disertai darah, sesak napas dan nyeri dada. Sedangkan pada pemeriksaan penunjang diantaranya pemeriksaan laboratorium terdapat peningkatan jumlah leukosit, biasanya lebih dari 10.000/ul kadang-kadang mencapai 30.000/ul, dan pada hitungan jenis leukosit terdapat pergeseran ke kiri serta terjadi peningkatan LED. Untuk menentukan diagnosis etiologi diperlukan pemeriksaan dahak, kultur darah dan serologi. Kultur darah dapat positif pada $20-25 \%$ penderita yang tidak diobati. Analisis gas darah menunjukkan hipoksemia dan hikarbia, pada stadium lanjut dapat terjadi asidosis respiratorik (PDPI, 2003).

Pengobatan pneumonia terdiri atas antibiotik dan pengobatan suportif. Pemberian antibiotic pada penderita pneumonia di dasarkan atas data mikroorganisme ( PDPI, 2003). Antibiotik yang digunakan untuk penyakit pneumonia adalah gologan $\beta$-laktam seperti sefalosporin dan golongan fluorokuinolon. Sefalosporin terbagi dalam empat generasi, sefalosporin G1 lebih aktif terhadap gram positif dan gerasi selanjutnya lebih sensitif terhadap bakteri gram negatif (Fida Amalia dkk., 2014).

Berdasarkan pembahasan diatas maka tujuan dari penelitian ini adalah untuk menganalisis efektifitas antibiotik terhadap perubahan suhu dan leukosit pada pasien pneumonia?

\section{METODE}

Penelitian ini merupakan penelitian studi non eksperimental yaitu cross sectional dan retrospektif. Penelitian di lakukan di Rumah Sakit Dr Soedono Madiun selama 3 bulan januari-maret 2019. 
Populasi penelitian adalah pasien rawat inap yang didiagnosis Pneumonia di Rumah Sakit dr. Soedono Madiun. Sampel penelitian ini adalah seluruh pasien yang didiagnosis Pneumonia dengan Antibiotik yang memenuhi kriteria inklusi dan di rawat inap di RS. Dr. Soedono Madiun. tehnik pengambilan data subjek yang didiagnosisi pneumonia secara purposive sampling data dan data yang diambil merupakan data yang telah memenuhi kriteria inklusi. Data yang akan diperoleh dari penelitian ini meliputi data demografi pasien, serta data suhu dan kadar Leukosit. uji normalitas datapada variabel penelitian yang berskala rasio seperti usia, jenis kelamin. Uji yang digunakan ialah ShapiroWilk karena jumlah sampel kecil (kurang dari 50). Pengujian mengetahui apakah terdapat perbedaan suhu dan kadar Leukosit pada to, dan t1 antar kedua waktu digunakan uji wilcoxon karana data terdistribusi tidak normal $(\mathrm{p}<0,05)$. Perbedaan kadar IFN- $\gamma$ dan IL-12 antar waktu diantara kedua kelompok menggunakan uji t bebas (independent ttest).

\section{HASIL}

Sampel penelitian selama 3 bulan yaitu Januari - Maret 2019 diperoleh 45 subjek yang memenuhi kriteria inklusi.

\section{Karakteristik awal pasien}

Karakteristik awal pasien meliputi jenis kelamin, usia dan lama Rawat Inap. Nilai $p$ value diuji dengan menggunakan uji chi-square, di tampilkan pda Tabel. 1

Tabel 1 Karakteristik awal pasien pneumonia

\begin{tabular}{|c|c|c|c|c|}
\hline \multicolumn{2}{|c|}{ Karakteristik Pasien } & \multicolumn{2}{|c|}{ Total Pasien } & \multirow[t]{2}{*}{ Nilai $p$} \\
\hline & & Jumlah (n) & Persentase (\%) & \\
\hline \multirow[t]{2}{*}{ Jenis Kelamin } & Laki-Laki & 25 & 55.56 & \multirow[t]{2}{*}{0,000} \\
\hline & Perempuan & 20 & 44,44 & \\
\hline \multirow[t]{5}{*}{ Usia } & $26-35$ & 4 & 8.89 & \multirow{5}{*}{0.14} \\
\hline & $36-45$ & 8 & 17.78 & \\
\hline & $46-55$ & 15 & 33.33 & \\
\hline & $56-65$ & 15 & 33.33 & \\
\hline & $>65$ & 3 & 6.67 & \\
\hline \multirow[t]{2}{*}{ Lama Rawat Inap } & $\leq 10$ hari & 37 & 82.22 & \multirow[t]{2}{*}{0,000} \\
\hline & $>10$ hari & 8 & 17.78 & \\
\hline
\end{tabular}


Pada penelitian ini terdapat 45 subjek dari hasil uji homogenitas terdapat perbedaan bermakna antara kelompok kontrol dan perlakuan $(\mathrm{p}>0,05)$.

\section{Hasil pengukuran Suhu dan Kadar leukosit Pasien Pneumonia}

Perubahan Suhu dan leukosit pada pasien pneumonia sebelum menerima terapi antibitik ditampilkan pada Tabel 2 .

Tabel 2. Profil Suhu dan kadar Pneumonia pada pasien sebelum dan sesudah menggunakan antibiotik Cefotaxime.

\begin{tabular}{ccccc}
\hline NO & Pre suhu $\left({ }^{\mathbf{O}} \mathbf{C}\right)$ & Post suhu $\left({ }^{\mathbf{O}} \mathbf{C}\right)$ & $\begin{array}{c}\text { Pre Leukosit } \\
\left(\mathbf{1 0}^{\mathbf{3}} \mathbf{x} \mathbf{L}\right)\end{array}$ & $\begin{array}{c}\text { Post Leukosit } \\
\left(\mathbf{1 0}^{\mathbf{3}} \mathbf{x} \mathbf{L}\right)\end{array}$ \\
\hline 1 & 39.01 & 36 & 12.3500 & 5.5000 \\
\hline 2 & 39.05 & 36 & 12.5500 & 5.6600 \\
\hline 3 & 39.02 & 37 & 14.3500 & 5.7200 \\
\hline 4 & 38.05 & 36.07 & 14.5500 & 5.7700 \\
\hline 5 & 39.04 & 37.09 & 14.5800 & 5.8200 \\
\hline 6 & 39.01 & 36.11 & 15.1000 & 5.8500 \\
\hline 7 & 40.05 & 37.13 & 15.3400 & 5.8900 \\
\hline 8 & 39.06 & 36.04 & 15.4000 & 5.9000 \\
\hline 10 & 40.02 & 37.04 & 17.2000 & 5.9800 \\
\hline 11 & 39.06 & 36.05 & 17.3000 & 6.0000 \\
\hline 12 & 40.03 & 37.05 & 17.3900 & 6.1000 \\
\hline 13 & 40.03 & 36.06 & 17.4500 & 6.1500 \\
\hline 14 & 39.03 & 37.06 & 19.2200 & 6.2000 \\
\hline 15 & 40.08 & 36.07 & 19.3200 & 6.2200 \\
\hline 16 & 38.02 & 37.07 & 19.3800 & 6.2400 \\
\hline 17 & 39.04 & 36.08 & 19.4500 & 6.2800 \\
\hline 18 & 40.03 & 37.08 & 19.5500 & 6.3000 \\
\hline 19 & 41.08 & 36.09 & 19.6000 & 6.3200 \\
\hline 20 & 39.06 & 37.09 & 19.6300 & 6.3400 \\
\hline 21 & 39.03 & 36.01 & 19.7200 & 7.0000 \\
\hline 22 & 38.02 & 37.01 & 19.8300 & 7.1000 \\
\hline Rata-Rata & 39.04 & 36.02 & 20.1200 & 7.1200 \\
\hline & 39.09 & 37.02 & 20.1700 & 7.1400 \\
\hline & 39.26 & 36.53 & 17.3717 & 6.2000 \\
\hline
\end{tabular}


Tabel 3. Profil Suhu dan kadar Pneumonia pada pasien sebelum dan sesudah menggunakan antibiotik Ciprofloxacin.

Pre Leukosit

Post Leukosit

\begin{tabular}{ccccc} 
NO & Pre suhu $\left({ }^{\mathbf{O}} \mathbf{C}\right)$ & Post suhu $\left({ }^{\mathbf{O}} \mathbf{C}\right)$ & $\left(\mathbf{1 0}^{\mathbf{3}} \mathbf{x} \mathbf{L}\right)$ & $\left(\mathbf{1 0}^{\mathbf{3}} \mathbf{x} \boldsymbol{L L}\right)$ \\
\hline 1 & 39.01 & 36.03 & 20.2300 & 7.1600 \\
\hline 2 & 40.04 & 37.03 & 10.0000 & 7.1800 \\
\hline 3 & 39.01 & 36.04 & 10.1000 & 7.2000 \\
\hline 4 & 39.03 & 37.04 & 10.1500 & 7.3000 \\
\hline Rata-Rata & 39.07 & 36.05 & 10.2500 & 7.2180 \\
\hline
\end{tabular}

Tabel 5.4 Profil Suhu dan kadar Pneumonia pada pasien sebelum dan sesudah menggunakan antibiotik Ceftazidim.

\begin{tabular}{ccccc}
\hline NO & Pre suhu $\left({ }^{\mathbf{0}} \mathbf{C}\right)$ & Post suhu $\left({ }^{\mathbf{0}} \mathbf{C}\right)$ & $\begin{array}{c}\text { Pre Leukosit } \\
\left(\mathbf{1 0}^{\mathbf{3}} \mathbf{x} \mathbf{L}\right)\end{array}$ & $\begin{array}{c}\text { Post Leukosit } \\
\left(\mathbf{1 0} \mathbf{x}^{\mathbf{3}} \boldsymbol{\mu} \mathbf{L}\right)\end{array}$ \\
\hline 1 & 40.01 & 37.05 & 10.3000 & 7.3300 \\
\hline 2 & 38.09 & 36.06 & 12.2000 & 8.000 \\
\hline 3 & 40.02 & 37.06 & 12.2200 & 8.1100 \\
\hline 5 & 38.09 & 36.07 & 12.3500 & 8.1300 \\
\hline 6 & 38.02 & 37.07 & 12.4000 & 8.1500 \\
\hline Rata-Rata & 38.04 & 36.08 & 13.0000 & 7.9817 \\
\hline
\end{tabular}

Tabel 5.5. Profil Suhu dan kadar Pneumonia pada pasien sebelum dan sesudah menggunakan antibiotik Gentamicin.

\begin{tabular}{ccccc}
\hline NO & Pre suhu $\left({ }^{\mathbf{O}} \mathbf{C}\right)$ & Post suhu $\left({ }^{\mathbf{O}} \mathbf{C}\right)$ & $\begin{array}{c}\text { Pre Leukosit } \\
\left(\mathbf{1 0}^{\mathbf{3}} \mathbf{x} \boldsymbol{\mu L}\right)\end{array}$ & $\begin{array}{c}\text { Post Leukosit } \\
(\mathbf{1 0} \mathbf{x} \boldsymbol{\mu L})\end{array}$ \\
\hline 1 & 40.09 & 37.08 & 13.2300 & 8.1900 \\
\hline 2 & 39.09 & 36.09 & 13.3100 & 8.2100 \\
\hline 4 & 39.08 & 37.09 & 13.3500 & 10.1000 \\
\hline 5 & 38.02 & 36.01 & 13.3700 & 10.1800 \\
\hline Rata-Rata & 40.01 & 37.02 & 14.0000 & 10.2000 \\
\hline
\end{tabular}


Tabel 5.6. Profil Suhu dan kadar Pneumonia pada pasien sebelum dan sesudah menggunakan antibiotik Cefepime.. Pre Leukosit

Post Leukosit

\begin{tabular}{ccccc} 
NO & Pre suhu $\left({ }^{\mathbf{O}} \mathbf{C}\right)$ & Post suhu $\left({ }^{\mathbf{o}} \mathbf{C}\right)$ & $\left(\mathbf{1 0}^{\mathbf{3}} \mathbf{x} \boldsymbol{\mu L}\right)$ & $\left(\mathbf{1 0}^{\mathbf{3}} \mathbf{x} \boldsymbol{\mu L}\right)$ \\
\hline 1 & 40.09 & 37.08 & 13.2300 & 8.1900 \\
\hline 2 & 39.09 & 36.09 & 13.3100 & 8.2100 \\
\hline 3 & 39.08 & 37.09 & 13.3500 & 10.1000 \\
\hline 4 & 38.02 & 36.01 & 13.3700 & 10.1800 \\
\hline Rata-Rata & 40.01 & 37.02 & 14.0000 & 10.2000 \\
\hline
\end{tabular}

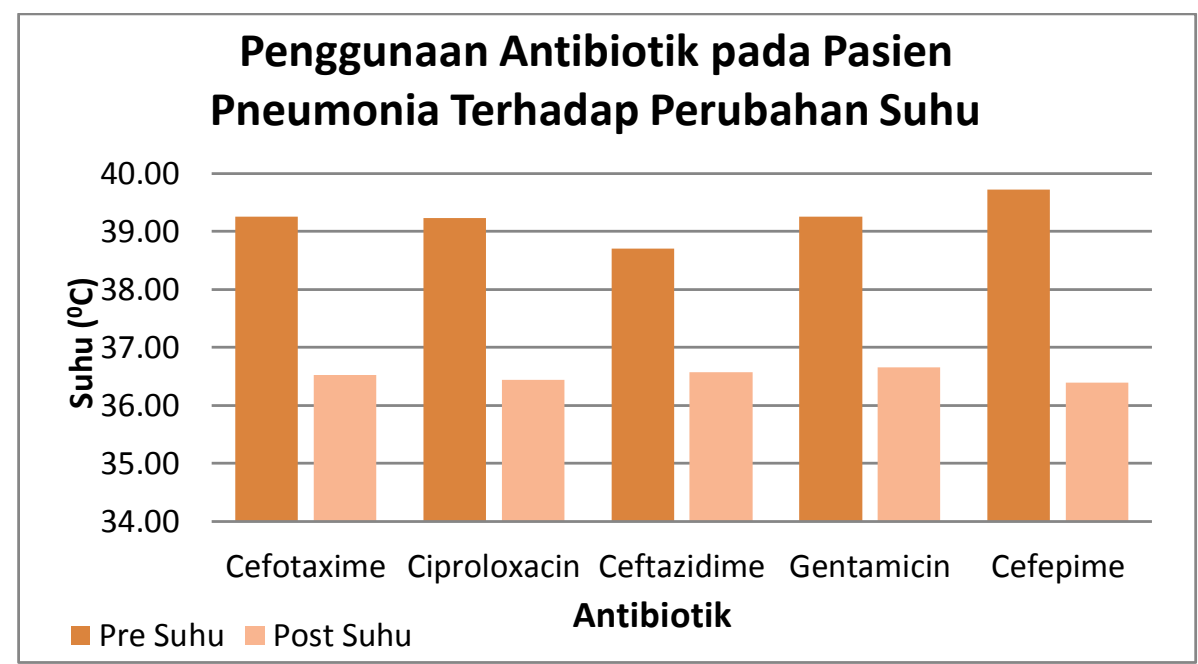

Gambar 5.1 Profil Suhu pada pasien sebelum dan sesudah menggunakan antibiotik.

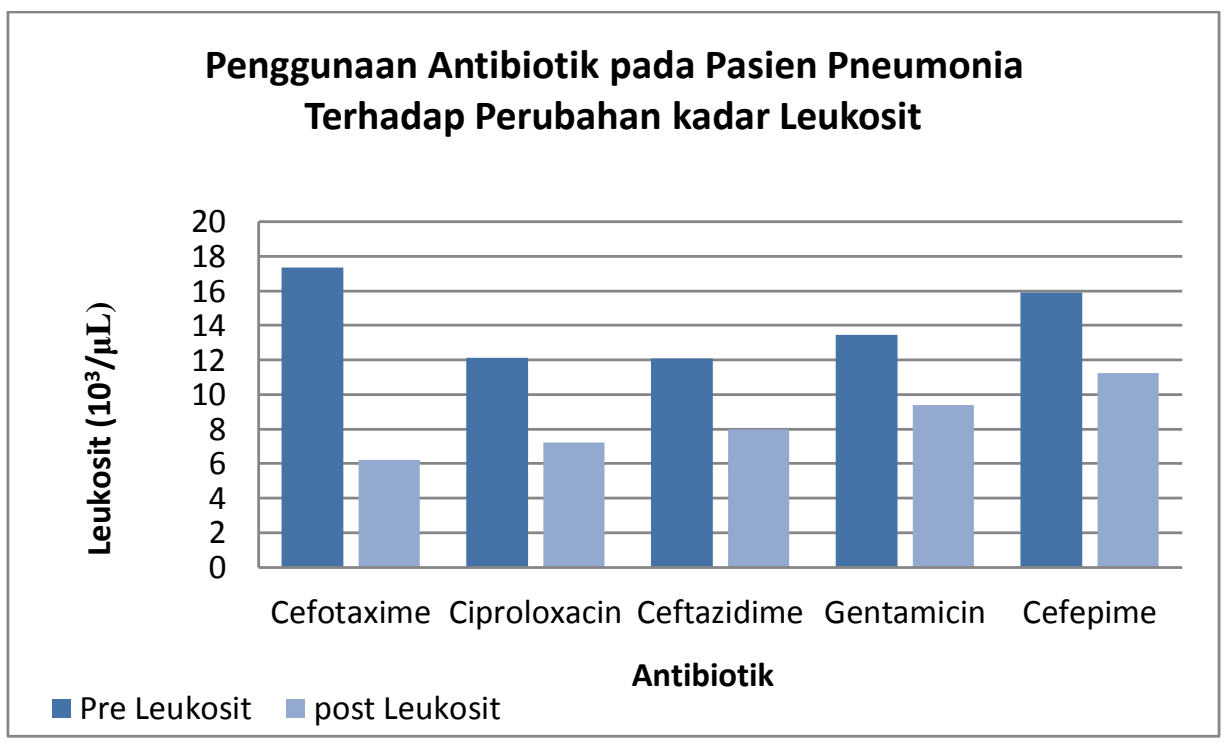

Gambar 2 Profil kadar Pneumonia pada pasien sebelum dan sesudah menggunakan antibiotik 
Berdasarkan Tabel 2, 3,4, 5, 6 serta gambar 1 dan 2 dapat diketahui bahwa suhu dan kadar Leukosit memiliki pola menurun setalah diberikan antibiotik.

\section{Analisis Statistik Uji uji perbandingan Suhu dan Kadar Leukosit sebelum dan setelah perlakuan.}

Setelah diketahui bahwa seluruh data tersebut terdistribusi normal maka akan dilakukan uji parametrik t berpasangan (paired $\mathrm{t}$ test) $(\mathrm{p}<$ $0,05)$ dan apabila data tidak terdistribusi normal maka akan dilakukan uji nonparametrik wilcoxon. ( $p>0,05)$.

Analisis statistik uji perbedaan kadar IFN- $\gamma$ dan IL-12 antar kelompok kontrol dan perlakuan, apabila terdistribusi normal maka akan dilakukan uji parametrik $\mathrm{t}$ bebas (independent $\mathrm{t}$ test) $(\mathrm{p}<0,05)$, apabila data tidak terdistribusi normal maka akan dilakuakan uji nonparametrik Mann Whitney $(\mathrm{p}>0,05)$.

Tabel 7. Profil Suhu dan kadar Pneumonia pada pasien sebelum dan sesudah menggunakan antibiotik.

\begin{tabular}{ccccccc}
\hline & $\begin{array}{c}\text { Pre } \\
\text { suhu }\left({ }^{\mathbf{0}} \mathbf{C}\right)\end{array}$ & $\begin{array}{c}\text { Post } \\
\text { suhu( }\left({ }^{\mathbf{0}} \mathbf{C}\right)\end{array}$ & Sig & $\begin{array}{c}\text { Pre } \\
\text { Leukosit } \\
\left(\mathbf{1 0}^{\mathbf{3}} \mathbf{x} \boldsymbol{L}\right)\end{array}$ & $\begin{array}{c}\text { Post } \\
\text { Leukosit } \\
\left(\mathbf{1 0}^{\mathbf{3}} \mathbf{x} \boldsymbol{\mathbf { L }}\right)\end{array}$ & Sig \\
\hline Cefotaxime & 39.26 & 36.53 & 0.000 & 17.3717 & 6.2000 & 0.000 \\
\hline Ciproloxacin & 39.23 & 36.44 & 0.043 & 12.1460 & 7.2180 & 0.042 \\
\hline Ceftazidime & 38.71 & 36.57 & 0.027 & 12.0783 & 7.9817 & 0.028 \\
\hline Gentamicin & 39.26 & 36.66 & 0.043 & 13.4520 & 9.3760 & 0.043 \\
\hline Cefepime & 39.73 & 36.39 & 0.028 & 15.8950 & 11.2250 & 0.028 \\
\hline
\end{tabular}

\section{PEMBAHASAN}

Pneumonia adalah suatu peradangan paru yang disebabkan oleh mikroorganisme (bakteri, virus, jamur, parasit), sedangkan peradangan paru yang disebabkan oleh nonmikroorganisme (bahan kimia, radiasi, aspirasi bahan toksik, obat-obatan dan lainlain) disebut pneumonitis. Insiden pneumonia komunitas dilaporkan meningkat sesuai dengan bertambahnya usia. Pada pasien usia $\geq 65$ tahun yang dirawat di rumah sakit (PDPI, 2003).
Diagnosis pneumonia komuniti didapatkan dari anamnesis, gejala klinis pemeriksaan fisis, foto toraks dan labolatorium. Diagnosis pasti pneumonia komuniti ditegakkan jika pada foto toraks terdapat infiltrat baru atau infiltrat progresif ditambah dengan 2 atau lebih gejala diantaranya batuk-batuk bertambah, perubahan karakteristik dahak / purulen, Suhu tubuh $>38^{\circ} \mathrm{C}$ (aksila) / riwayat demam, pemeriksaan fisis : ditemukan tanda-tanda konsolidasi, suara napas bronkial dan ronki, 
Leukosit > 10.000 atau < 4500 (PDPI, 2003 )

Penatalaksanaan Pneumonia dibagi menjadi tiga yaitu, bagi penerita rawat jalan, rawat inap dan rawat inap di ruang intensif. Pada penderita yang di rawat inap makan yang diberikan adalah pengobatan suportif/ simptomatik diantaranya pemberian terapi oksigen, pemasangan infus untuk dehidrasi dan koreksi kalori dan elektrolit, pemberian obat simptomatik antara lain antipiretik, mukolitik serta pemebrian antibiotik kurang dari 8 jam (PDPI, 2003).

Pada penelitian ini subjek berjenis kelamin Laki-laki (44.56\%) lebih banyak dibandingkan dengan perempuan $(44,44 \%)$. Hal seperti yang dikatakan oleh Dahlan (2006) yang menyatakan bahwa jenis kelamin laki-laki mempunyai banyak faktor yang dapat meningkatkan risiko terjadinya pneumonia diantarannya karena kebiasaan merokok, penyakit kronis, rentang keadaan imunodifisiensi, faktor lingkungan serta gaya hidup (Dahlan, 2007).

Rentang usia subjek penelitian ini adalah 31 tahun sampai lebih dari 65 tahun. Dimana yang paling banyak didiagnosis pneumonia adalah umur 46-65 tahun sebanyak 30 pasien. Hal ini sesuai dengan penelitian sebelumnya yang menyatakan bahwa imunitas tubuh akan menurun seiring dengan bertambahnya usia seseorang. Penurunan system imunitas tubuh dapat disebabkan karena menurunya kemampuan tubuh untuk memprodiksi hormone timus, akibatnya tubuh akan mudah terserang virus dan bakteri. (Price, 2006).

Lama rawat inap $\leq 10$ hari sebanyak $82.22 \%$ dan > 10 hari $17.78 \%$. Nilai distribusi pasien rawat inap pada pasien pneumonia sesuai dengan Depkes(2005) yang menyatakan rawat inap ideal adalah 6-9 hari. Berbeda dengan pernyataan PDPI (2016) menyatakan berdasarkan hasil penelitian pasien pneumonia yang dirawat $>9$ hari, lebih cepat memberikan respon pada perbaikan kondisi (Depkes 2005., PDPI, 2016).

Penggunaan antibiotik untuk penyakit pneumonia pada penelitian ini menggunakan lima antibitik yaitu Cefotaxime, Ceftazidim, Cefepime, Ciprofloxacin dan Gentamicin.

Cefotaxime dan ceftazidim adalah antibiotik golongan cefalosporin generasi ketiga dimana memiliki aktifitas yang luas baik terhadap bakteri gram positif dan gram negative. serta aktif melawan $S$. 
Pneumonia.golongan cefalosporin jugadapat menetrasi cairan dari jaringan tubuh dengan baik. Pada penelitian Menon, dkk (2013) menyatakan bahwa cefotaxime memiliki sensivitas yang tinggi daripada antibiotic lain pada penyakit pneumonia. Sedangkan Petri (2011) menyatakan bahwa ceftazidim memiliki aktivitas yang baik terhadap Pseudomonas dan bakteri gram negative lainnya.

Cefepime adalah antibiotic golongan cefalosporin generasi ke empat yang efektif untuk terhadap infeksi baik yang disebabkan oleh bakteri gram positif maupun bakteri gram negatif seperti infeksi. Pseudomonas aeruginosa, K. Pneumoniae, E Coli dan Eterobacter. Cefepime juga bekerja menghambat sintesis dinding sel (Depkes, 2005., Depkes, 2014).

Gentamicin merupakan golongan aminoglikosida yang mempunyai spectrum luas dan bersifat bakterid, untuk menembus dinding bakteri mencapai robosom, aminoglikosida yang bermuatan kation positif akan berikatan secara pasif dengan membran luar dinding kuman gram negatif yang mengandung muatan negative pada pneumonia Ciprofloxacin merupakan antibiotic golongan Quinolon yang merupakan antimicrobial yang memberikan pengaruh terhadap pengaruh infeksi. Mekanisme golongan Quinolon secara umum adalah dengan menghambat DNA-gyrase. Ciprofloxacin juga lebih aktif terhadap kuman gram negative (Kang and Lee, 2009).

\section{KESIMPULAN}

Berdasarkan hasil penelitian efektifitas antibiotik terhadap perubahan suhu dan kadar leukosit pada pasien pneumonia, maka dapat disimpulkan bahwa pemberian antibiotik dapat menurunkan suhu dan kadar leukosit pada perwatan selama beberapa hari secara bermakna.

\section{DAFTAR PUSTAKA}

Dahlan Z. Pneumonia.Buku Ajar Ilmu Penyakit Dalam.Vol 2. 6 ed. In: W.Sudoyo A, Setiyohadi B, Alwi I, K. MS, Setiati S, editors. Jakarta: Pusat Penerbitan Departemen Ilmu Penyakit Dalam Fakultas Kedokteran Universitas Indonesia., 2014.

Dahlan Z., Buku Ajar Ilmu Penyakit dalam FKU: Pneumonia. Jakarta. 2007.

Departemen Kesehatan RI. Riset Kesehatan Dasar (Riskesdas) Laporan Nasional 2013. Jakarta. 2014.

Depkes RI, Pharmaceutical Care Untuk Infeksi Saluran Pernapasan, Departemen Kesehatan RI, Jakarta., 2005.

Fida Amalina. Pneumonia Can Be prevented. Univesitas Diponegoro., 2014. 
Kang JS dan Lee MH., Overview of Therapeutic Drug Monitoring, The Korean Journal of Internal Medicine. 2009

Kang JS dan Lee MH., Overview of Therapeutic Drug Monitoring, The Korean Journal of Internal Medicine. 2009

Menon R, Gerorge A, Menon U. Etiology and Anti-microbial Sensitivity of Organisms Causing Community Acquired Pneumonia: A Single Hospital Study. Journal of Family Medicine and Primary Care. 2013.

Nur, Deasy, .Efektivitas penggunaan Antibiotik Ceftriaxone pada pasien Pneumonia dewasa di instalasi rawat inap RSUD.MOEWARDI .Surakarta. Universitas Sebelas Maret., 2016.
Perhimpunan Dokter Paru Indonesia (PDPI). Pneumonia Komuitas. Pendoman Praktiks Diagnosis dan Penatalaksanaan di Indonesia. Jakarta: Balai Penerbit FKUI. 2014.

Perhimpunan Dokter Paru Indonesia (PDPI). Pneumonia Komuitas. Pendoman diagnosis dan penatalaksanaan di Indonesia. Jakarta: Balai Penerbit FKUI. 2003.

Petri Jr WA. Penicillin, Cephalosporins and Other $\beta$ - lactam antibiotics. Dalam: Goodman \& Gillman's, The Pharmacological Basis of Therapeutics, 2006., edisi XL 1127-2254

Price, S, A dan Wilson, L, M. Patofisiolgi Konsep Klinis Proses-proses penyakit, Edisi 6, Volume 2, Jakarta., 2006. 